\title{
Correction to: Mesoscale and submesoscale mechanisms behind asymmetric cooling and phytoplankton blooms induced by hurricanes: a comparison between an open ocean case and a continental shelf sea case
}

\author{
Laura McGee $^{1} \cdot$ Ruoying $\mathrm{He}^{1}$ (D) \\ Published online: 20 April 2020 \\ (C) Springer-Verlag GmbH Germany, part of Springer Nature 2020
}

Correction to: Ocean Dynamics (2018) 68:1443-1456

https://doi.org/10.1007/s10236-018-1203-3

The original version of this article unfortunately contained a mistake. The following data attribution statement per our research sponsors requirement has been omitted.

"This research was made possible by a grant from The Gulf of Mexico Research Initiative. Data are publicly available through the Gulf of Mexico Research Initiative Information \& Data Cooperative (GRIIDC) at https://data. gulfresearchinitiative.org (https://doi.org/10.7266/n7-ggxhqh48)"

The online version of the original article can be found at https://oi.org/ 10.1007/s10236-018-1203-3

Ruoying He

rhe@ncsu.edu

1 Department of Marine, Earth and Atmospheric Sciences, North

Carolina State University, Raleigh, NC 27695, USA 